\title{
The role of eosinophilopoietins and integrins on eosinophils biology in asthma
}

\author{
EOZINOFILOPOETINŲ IR INTEGRINŲ VAIDMUO EOZINOFILŲ BIOLOGINĖMS \\ SAVYBËMS SERGANT ASTMA
}

\author{
JOLITA PALACIONYTE ${ }^{1}$, ANDRIUS JANUSKEVICIUS ${ }^{2}$, KESTUTIS MALAKAUSKAS ${ }^{1,2}$ \\ ${ }^{1}$ Department of Pulmonology, Lithuanian University of Health Sciences, ${ }^{2}$ Laboratory of Pulmonology, \\ Department of Pulmonology, Lithuanian University of Health Sciences
}

\begin{abstract}
Summary. Asthma is a chronic inflammatory airway disease that affects about 300 million people worldwide, and the incidence is continuously increasing. Patients with asthma are most commonly diagnosed with type 2 inflammation, which is characterized by eosinophilia, which is an increased amount of eosinophils in the blood and airways. Asthma with predominant eosinophilic inflammation is characterized by a more severe course of the disease, more frequent exacerbations, and more intense symptoms. To reduce symptoms, facilitate the course of the disease, and treat asthma more effectively is important to understand asthma pathogenesis better. Eosinophils survival maturation, activation, and quantity in the lungs are promoted by cytokines, of which eosinophilopoietins - interleukin (IL) 3, IL-5, and granulocyte-macrophage colony-stimulating factor (GM-CSF) are the most important. Eosinophilia is also associated with the activation of integrins present on the surface of eosinophils. Integrins are responsible for eosinophils adhesion to airway structural cells, thus prolonging their survival leading to more intense airway eosinophilia. Eosinophilopoietins, their receptors, and integrins might be suitable targets reducing eosinophilia in blood and airway, as well as airway inflammation. Humanized monoclonal antibodies are used for this purpose. Biological therapy allows for the specific inhibition of relevant asthma pathways and offers patients individualized treatment. This review will discuss the biological significance of eosinophilopoietins and their receptors, integrins on eosinophils functions, anti-cytokine and anti-integrin therapy efficiency in asthma.
\end{abstract}

Keywords: eosinophils, eosinophilopoietins, interleukin 3, interleukin 5, granulocyte-macrophage colony-stimulating factor, integrins, asthma.

Santrauka. Astma yra uždegiminè kvèpavimo takų liga, kuria serga apie 300 milijonų žmonių visame pasaulyje, o sergamumas nuolat didejja. Sergantiesiems astma dažniausiai nustatomas 2 tipo uždegimas, kuriam būdinga eozinofilija, tai yra padidẻjęs eozinofilų kiekis kraujyje ir kvėpavimo takuose. Astma su vyraujančiu eozinofiliniu uždegimu pasižymi sunkesne ligos eiga, dažnesniais paūmèjimais, intensyvesniais simptomais. Siekiant to išvengti ir pagerinti gydymo rezultatus svarbu geriau suprasti astmospatogenezę. Eozinofilų išgyvenamumą, aktyvinimą ir jų telkimasi plaučiuose bei kraujyje lemia citokinai, iš kurių svarbiausi - interleukinas (IL)-3, IL-5 ir granuliocitų-makrofagų kolonijas stimuliuojantis veiksnys (GM-CSF). Eozinofilija taip pat susijusi su eozinofilų paviršiuje esančių integrinų aktyvinimu. Integrinai yra atsakingi už eozinofilų sukibimą su kvèpavimo takų struktūrinèmis ląstelèmis. Taip prailginamas eozinofilų išgyvenamumas, o tai lemia ryškesnę kvèpavimo takų eozinofiliją. Siekiant mažinti eozinofiliją, kartu ir kvejpavimo takų uždegimą, eozinofilopoetinai, jų receptoriai ir integrinai gali būti potencialūs taikiniai gydymui. Šiam tikslui pasiekti naudojami humanizuoti monokloniniai antikūnai. Biologinè terapija yra perspektyvi individualizuojant astmos gydymą, nes leidžia specifiškai slopinti svarbius astmos kelius. Šioje apžvalgoje bus aptarta eozinofilopoetinų ir jų receptorių biologinè reikšmė, integrinų poveikis eozinofilų funkcijoms, anticitokinų ir antiintegrinų terapijos veiksmingumas sergant astma.

Reikšminiai žodžiai: eozinofilai, eozinofilopoetinai, interleukinas 3, interleukinas 5, granuliocitų-makrofagų kolonijas stimuliuojantis veiksnys, integrinai, astma.

\section{INTRODUCTION}

Asthma is one of the most common chronic diseases which affects about 300 million people worldwide. This disease affects people in all countries; however, the prevalence of asthma is greatest in developed western countries. People with asthma experience shortness of breath, cough, wheezing, and tightness in the chest. All these symptoms are associated with airway obstruction caused by bronchial hyperresponsiveness and airway inflammation. Immune cells exposed to cytokines and growth factors cause various structural changes in the airways called airway remodeling [1]. Although asthma is usually easily controlled with standard treatment, nevertheless, disease control is not always 


\section{Moksliniai darbai ir apžvalgos}

achieved. About 5-10 percent of patients suffer from uncontrolled or severe asthma and results in increased mortality, hospitalizations, poor quality of life, and increased health care costs [2,3].

Asthma is a more complex disease than previously thought, manifesting itself in several different phenotypes whose pathogenesis is also different. Approximately half of the patients who have asthma have predominant eosinophilic inflammation, and eosinophils counts in the airways are associated with the disease severity [4]. Eosinophils differentiation is promoted by cytokines - interleukin (IL) 3, IL-5, granulocyte-macrophage colony-stimulating factor (GM-CSF) [5] which belong to the $\beta$-chain cytokines family. These cytokines are principally produced by activated T cells [6]. Eosinophilopoietins form a group of pro-inflammatory cytokines that signal via a receptor complex composed of a cytokine-specific $\alpha$ chain and the $\beta c$ homodimer [7]. IL-3, IL-5 and GM-CSF possess unique characteristics to activate eosinophils; that way, different cytokines can differentially affect eosinophils functions [8]. Eosinophilopoietins are important in maintaining health and developing the disease. Their significant effect has been found in the development of eosinophilic inflammation in the airways [9]. For this reason, anti-cytokine and anti-cytokine receptor antibodies are considered as an effective therapy for asthma patients who are not responding to conventional treatment [10].

Integrins determine adhesion processes essential for cell development, immune responses, and hemostasis. Moreover, they act as signal-transducing receptors that can control intracellular pathways and regulate cell survival, proliferation, and cell fate [11]. Integrins manage the extravasation of eosinophils from the postcapillary segment of the bronchial circulation to the airway wall and airspace for patients with asthma. Eosinophils possess a unique repertoire of seven integrins heterodimers [12]. Integrins dysregulation, due to their expression in the lungs, may contribute to the development of respiratory diseases, thus integrinstargeted therapy hold great potential for the treatment of respiratory diseases in the future [13].

We will discuss the biological significance of eosinophilopoietins, their receptors, and outer-membrane integrins to eosinophils functions. Moreover, we will relate the potential of anti-cytokine and anti-integrin therapy effects on eosinophils functions and its efficiency in asthma treatment.

\section{METHODS}

The scientific review presents information obtained from freely accessible scientific periodicals published abroad with a citation rate in the Clarivate Analytics Web of Science, Scopus, and Springerlink databases.
The information was collected using the National Center for Biotechnology Information (NCBI) PubMed and PMC, Google Scholar, and the Wiley Online Library search engines. The following keywords were used to collect the information: asthma, eosinophils, cytokines, $\beta$ common chain cytokines, eosinophilopoietins, IL-3, IL-5, GM-CSF, $\beta$ chain-signaling cytokines receptors, integrins, anti-cytokine, and anti-integrin therapy.

\section{THE BIOLOGY OF EOSINOPHILS AND THEIR ROLE IN ASTHMA}

Eosinophils are terminally differentiated, bone marrow-derived, granule-containing leukocytes, as are neutrophils, basophils and mast cells [14]. The number of eosinophils generated from the bone marrow in healthy individuals is low, resulting in relatively few cells circulating systemically [15]. Eosinophils were identified and described by Paul Ehrlich in 1879 after eosin dyes were first used. Typically $0.5 \times 10^{9} / \mathrm{L}$ absolute eosinophils counts are the upper limit of normal and eosinophil counts exceeding $\geq 0.5 \times 10^{9} / \mathrm{L}$ are reported as elevated. An increased number of eosinophils in the tissues and/or blood are called eosinophilia [16]. Eosinophils in blood live from 16 to 36 hours. After circulating in the blood, eosinophils migrate into the tissues and live there from 2 to 5 days [17]. Eosinophils in the blood and tissues of individuals with asthma have been shown to live longer than in healthy individuals. Eosinophils apoptosis can be delayed by a variety of factors, with a prolongation of survival of up to 1-2 weeks.

Eosinophils are involved in defensive reactions against parasites and viruses, and are known to promote allergic reactions. After migrating to the tissues, these cells actively regulate various immune responses through the release of biologically active substances [16]. Eosinophils typically contain about 200 morphologically distinct cytoplasmic granules, containing many toxic proteins and other mediators that enhance the inflammatory response and cause tissue damage [18]. Eosinophils themselves are a source of over 35 cytokines, chemokines, and growth factors [15]. The link between eosinophils and asthma was first established about a century ago. A close relation between eosinophilia, exacerbations of asthma, and deterioration in lung function have been proven. Airway eosinophilia also contributes to the development of airway remodeling, and eosinophils' role in disturbing local homeostasis is indisputable [19].

\section{ROLE OF EOSINOPHILOPOIETINS ON EOSINOPHILS FUNCTIONS}

Airway inflammation in asthma is regulated by the cytokine network [3] that owns excess of 50 cytokines [20]. The main cytokines that affect eosinophils are 


\section{Moksliniai darbai ir apžvalgos}

IL-3, IL-5, and GM-CSF. They belong to the $\beta$-chain cytokines family [8]. These cytokines are called eosinophilopoietins $[8,21]$. IL-3, IL-5, and GM-CSF are mostly produced by activated $\mathrm{T}$ cells and characterized by the same receptor structure, comprising a cytokine-specific $\alpha$ chain and a common $\beta$ chain $(\beta c)$ [22]. Eosinophilopoietins cause eosinophils maturation, activation and accumulation in the lungs [21]. Excessive expression of IL-3, IL-5, GM-CSF can lead to excessive signal transduction and alter the course of the disease [23].

IL-3, IL-5, and GM-CSF have wide-ranging effects on eosinophils [24]. IL-3 and GM-CSF are far more pleiotropic than IL-5, but all three are thought to have mostly redundant functions on eosinophils [25]. IL-5 promotes eosinophils proliferation and differentiation; IL-3, IL-5, and GM-CSF have important effects on survival, trafficking, degranulation, and also activation of eosinophils (Figure 1). IL-3 and IL-5 are expressed mainly by activated T lymphocytes and mast cells. GM-CSF is produced by T cells, epithelial cells, and macrophages [23]. The impact of each cytokine on eosinophil biology is similar but has some different aspects. IL-3 and GM-CSF are crucial in the early eosinophils development stages, while IL-5 is important for final maturation during eosinophil differentiation. Human bone marrow activated with IL-5 forms colonies of highly pure and mature eosinophils, while IL-3 or GM-CSF forms more colonies, but with less mature eosinophils [8]. All three $\beta$-chain cytokines play a vital role in the growth and survival of eosinophils [26]. IL-3, IL-5, and GM-CSF have similar effects on eosinophil adhesion and comparable efficacy to induce eosinophil transmigration through a layer of epithelial cells via the $\beta 2$ integrin [8]. Due to the abovementioned properties, IL-3, IL-5, and GM-CSF are considered as a potential target in asthma therapeutics [27]; however, IL-5 was selected as a priority target to reduce eosinophilia because it is highly specific for eosinophilic inflammation [28].

Not only cytokines but also their receptors play an important role in the recruitment process of eosinophils in asthma. IL-3, IL-5, and GM-CSF share a common $\beta$-chain and have their cytokine-specific $\alpha$-chains. The IL- 5 receptor is fairly specific since it is only expressed on eosinophils and basophils, while receptors for IL-3 and GM-CSF are present on many haematopoietic cells [28]. Despite all three cytokines sharing a standard beta $(\beta)$ chain receptor subunit, each differentially affects eosinophils biology due to alpha ( $\alpha$ ) chain subunit-specific properties [27]. The cytokines attach to their respective $\alpha$-chain with low affinity (nanomolar); on the other hand, subsequent recruitment of the $\beta$-chain contributes to a conformational change to a great affinity (picomolar) binding complex [8]. Assembly of the IL-3, IL-5, and GM-CSF receptors are shown in Figure 2.

Activation of $\beta$-chain cytokines receptors by eosinophilopoietins leads to eosinophils pre-activation, required for regulation of their surface proteins expression, including integrins [30]. Eosinophils activation by IL-3, IL-5, or GM-CSF depends on the concentration of these cytokines and the amount of $\beta$-chain cytokines receptors on eosinophils surface. However, exist and important cross-regulation between these cytokines concentrations and expression of their receptors [31]. The study demonstrated that all eosinophilopoietins down-regulate IL-5R $\alpha$ and up-regulate IL-3R $\alpha$ expression, while GM-CSFRa is down-regulated by GM-CSF itself, but are not affected by IL-3 or IL-5. This study was completed with healthy subjects eosinophils.

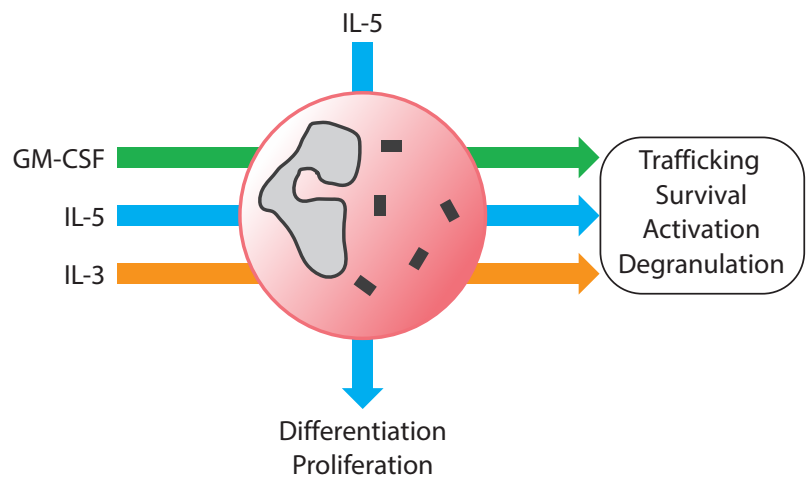

Figure 1. The effect of major stimulatory cytokines on eosinophils [24]

IL-5 promotes eosinophil differentiation and proliferation. IL-5, GM-CSF, and IL-3 all have important effects on trafficking, survival, degranulation, and activation of eosinophils. IL-3 - interleukin-3; IL-5 - interleukin-5; GM-CSF granulocyte-macrophage colony-stimulating factor.

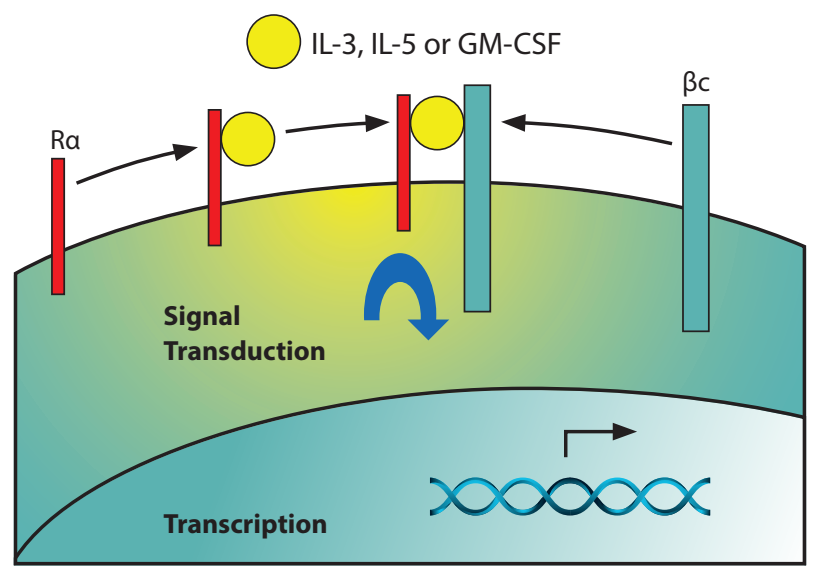

Figure 2. Assembly of the IL-3, IL-5, and GM-CSF receptors [29]

IL-3Ra, IL-5Ra, and GM-CSFRa exist as monomers on unstimulated cells. Each Ra chain provides cytokine binding specificity. On ligand binding, $\beta c$ is recruited to the $R a /$ ligand complex and interacts with the Ra-bound cytokine to activate signal transduction and physiologic response. $R a-$ receptor a; IL-3Ra - interleukin-3 receptor a chain; IL-5Ra - interleukin-5 receptor a chain; GM-CSFRa - granulocyte-macrophage colony-stimulating factor receptor $a$ chain; $\beta c-\beta$ chain. 


\section{Moksliniai darbai ir apžvalgos}

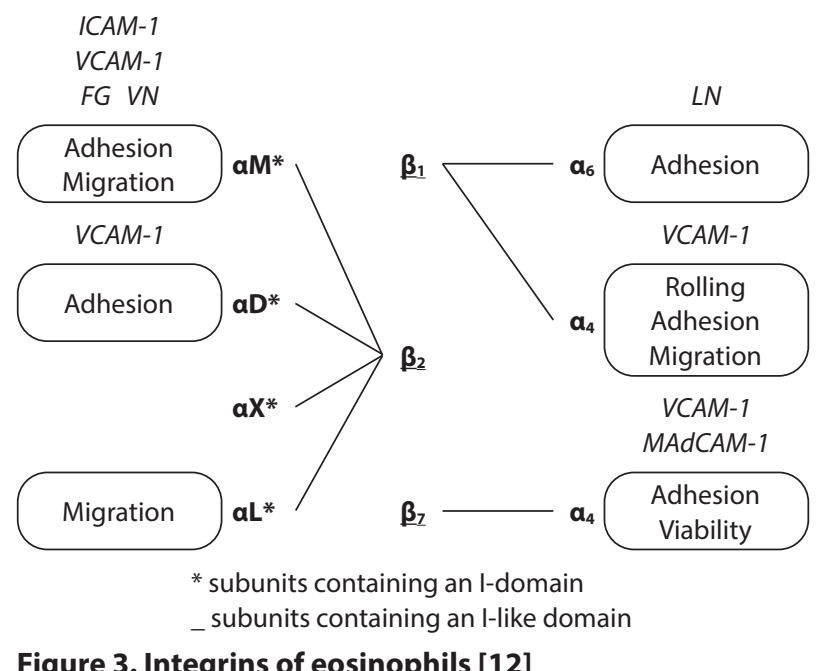

Functions and ligands assigned to integrins have been deduced in various assays using eosinophils. ${ }^{*}$, Subunits that contain the insert (I)-domain. Subunits that are underlined contain the I-like domain. MAdCAM-1, Mucosal addressin cell adhesion molecule-1; FG, fibrinogen; LN, laminin; VN, vitronectin. ICAM-1 - intercellular adhesion molecule-1; VCAM-1 - vascular cell adhesion molecule; FG - fibrinogen; VN - vitronectin; LN - laminin; MAdCAM-1 - Mucosal addressin cell adhesion molecule-1.

However, in asthma, the cross-regulation is similar. It was revealed that serum levels of IL-3 do not change during asthma, however, expression of this cytokine's receptors in eosinophils is significantly up-regulated. The concentration of GM-CSF is increased in the serum of allergic and severe non-allergic eosinophilic asthma (SNEA) patients. Still, the expression of its receptors do not change in eosinophils from SNEA patients and is significantly reduced in allergic asthma (AA) phenotype. Finally, the dominance of the IL-5 signaling pathway was revealed in SNEA patients. Even in AA and SNEA patients, the serum levels of IL-5, especially in the SNEA group, were increased, however, an important shift from down-regulation in AA to up-regulation in SNEA eosinophils was detected [32]. These data show that the severe course of the disease might be related to the increased IL-3, GM-CSF, and especially IL-5 signaling.

\section{ROLE OF INTEGRINS ON EOSINOPHILS FUNCTIONS}

Eosinophils migration from the bloodstream into various tissues results from a specific interaction between integrins on the surface of eosinophils with adhesion receptors on the surface of the vascular endothelium and cells in the tissues that mediate transmigration process. Blood eosinophils can enter the airways after firm adhesion to vascular endothelium cells and diapedesis [33]. Eosinophils express $\alpha_{4} \beta_{1}, \alpha_{6} \beta_{1}, \alpha \mathrm{L} \beta_{2}, \alpha \mathrm{M} \beta_{2}, \alpha \mathrm{XX} \beta_{2}, \alpha \mathrm{D} \beta_{2}$, and $\alpha_{4} \beta_{7}$ integrin dimers (Figure 3 ). All of them regulate the extravasation of eosinophils from the bronchial circulation to the airway wall and airspace under the control of sev- eral chemoattractants $[12,34]$. Whereby integrins on circulating eosinophils become activated, eosinophils tether inflow, and roll on bronchial endothelial cells (Figure 4). With continued cytokine activity, eosinophils activation continues, and eosinophils with the help of adhesion molecules migrate to the airways. Integrins expression and their activation state are essential for more stable and increased adhesion, and adhesion-related eosinophils activation after interacting with counter-receptors on other cells or ligands in the extracellular matrix $[11,26]$.

$\alpha_{4} \beta_{1}$ and $\alpha \mathrm{M} \beta_{2}$ are the most important and most studied eosinophils integrins [35]. $\alpha_{4} \beta_{1}$ and $\alpha M \beta_{2}$ are differentially expressed following exposure to GM-CSF and different redox agents. $\alpha_{4} \beta_{1}$ largely responsible for the arrest of blood eosinophils in vessels of the asthmatic lung, while $\alpha \mathrm{M} \beta_{2}$ is involved in subsequent eosinophils recruitment to and persistence in the extracellular matrix of the bronchi in asthma [35]. Previously was demonstrated that gene expression of $\alpha \mathrm{M}, \beta_{2}, \alpha_{4}$, and $\beta_{1}$ integrins subunits are enhanced in eosinophils from stable AA patients [36]. Moreover, another study revealed that $\alpha \mathrm{M}, \alpha_{4}$, and $\beta_{1}$ subunits are differently expressed in SNEA patients, compared with AA [32]. Altered integrins expression suggest their potential role as a target for eosinophilic inflammation treatment in asthma.

Eosinophils can interact with ligands, including vascular cell adhesion protein 1 (VCAM-1), intercellular adhesion molecule 1 (ICAM-1), laminin, fibrinogen/ fibrin, vitronectin, and periostin [38-40]. Integrindependent adhesion also acts as a signal transducer and can control cell biologies, such as growth, division, survival, cellular differentiation, and apoptosis [41]. $\alpha \mathrm{M} \beta_{2}$ is influenced greatly by activation with IL-5, which enhances $\alpha \mathrm{M} \beta_{2}$-mediated adhesion of blood eosinophils to ICAM-1 or modules 1 or 4 of VCAM- 1 [42]. IL-5-related $\alpha \mathrm{M} \beta_{2}$ activation could be a potential target to reduce eosinophilia, as IL-5 levels are significantly increased in asthma [43]. Moreover, it is known that IL-5, IL-3, or GM-CSF stimulated eosinophils to adhere to periostin through $\alpha \mathrm{M} \beta_{2}$ integrin leading to increased eosinophils infiltration in the lungs, as periostin levels are also increased in AA and SNEA patients [40].

\section{ANTI-CYTOKINE AND ANTI-INTEGRIN THERAPY IMPACT ON EOSINOPHILS FUNCTIONS IN ASTHMA PATIENTS}

Profound studies of the molecular mechanisms of asthma carried out since the 1990s, implicated cytokines, and their receptors in the maintenance and initiation of asthma. These findings led to anticytokine therapy to become a potential asthma treatment. Many of the eosinophil's functions are controlled 


\section{Moksliniai darbai ir apžvalgos}

by IL-5. Two ways are available to regulate IL-5 and the eosinophil's participation in asthma. One of them is a monoclonal antibody directed against the cytokine IL-5, another - a monoclonal antibody that targets its receptor. Both approaches are effective in reducing circulating eosinophils, and with a reduction in circulating eosinophils, fewer of these cells are available for migration to the airway. Mepolizumab and reslizumab are directed against IL-5, benralizumab - against the IL-5R. All of these medications lower the asthma exacerbation rate, improve quality of life, and ameliorate asthma symptoms [44, 51-58]. One of the limiting issues with monoclonal antibodies is their ability to access the inflammation site where the cytokines are acting. Thus, an anti-IL-5 antibody will not shorten the survival of eosinophils already present in the airway. In contrast anti-receptor antibodies can bind to tissues eosinophils and shorten the survival of already infiltrated eosinophils as well. It is an important difference between anti-cytokine and anti-receptor antibodies. That causes the higher capacity of anti-IL-5R to eliminate tissue eosinophils in contrast to anti-IL-5 antibodies [45].

The initial results of clinical trials investigating mepolizumab were disappointing. Mepolizumab diminished blood eosinophils but did not manage to improve any clinically important outcome. It is believed that this happened because asthma is a heterogeneous disease, and anti-IL-5 antibodies are effective only for some asthma phenotypes. The patients included in the initial study were not selected by eosinophil count [46]. Later in trials were involved patients who had at least two exacerbations in the previous year despite receiving high-dose of inhaled corticosteroids and with blood eosinophils counts of $\geq 300$ cells $/ \mu \mathrm{L}$ or sputum eosinophils count $\geq 3$ percent. Mepolizumab efficacy has been investigated in a total of five trials $[47,51-55]$. Phase 3 studies on mepolizumab for severe eosinophilic asthma are presented in Table 1.

Reslizumab efficacy has been investigated in four trials $[47,48,56]$. Initial data from the early stages of the reslizumab clinical development program were discouraging. It was because of a lack of patient selection. A phase 1 pilot trial of reslizumab in a small number of patients with severe persistent asthma failed to demonstrate a significant improvement in asthma symptoms and lung function $[49,66]$. However, this study has important implications as it was the first to demonstrate that reslizumab can effectively and safely decrease eosinophil counts in patients with asthma. This study highlighted the importance of adequately preselection of patients whose asthma is dependent on the eosinophilic inflammation pathway, and this led the incorporation of appropriate patient selection. The main phase II 3 studies results are presented in Table 1. It is important to mention that in the studies with reslizumab asthmatics were enrolled with baseline blood eosinophils $>400$ cells/ $\mu \mathrm{L}$. Reslizumab is different from other anti-IL-5 antibodies because it is currently available as an intravenous formulation, and the development of a subcutaneous formulation is ongoing [49].

Benralizumab is a biologic drug that specifically binds to the IL- 5 receptor, thus preventing the interaction with its ligand and the consequent pro-inflammatory effects [50]. It is efficacy has been investigated in six clinical trials. Clinical trials have revealed the high efficacy and good tolerability of benralizumab in patients with eosinophilic asthma. Two of the trials were the 2 phase [48]. Benralizumab was tested in a phase $2 \mathrm{a}$ and phase $2 \mathrm{~b}$ randomized, dose-ranging trials. The results showed that benralizumab improved expiratory volume $\left(\mathrm{FEV}_{1}\right)$ within 1 second, caused a marked decrease in the number of peripheral blood eosinophils, reduced the number of exacerbations of 


\section{Moksliniai darbai ir apžvalgos}

Table 1. Phase 3 studies on anti-IL-5 therapies for severe eosinophilic asthma

\begin{tabular}{|l|l|c|c|l|c|c|}
\hline \multicolumn{1}{|c|}{ Study } & Medication & Patients & Duration & Primary outcomes & References \\
\hline DREAM study & Mepolizumab & 621 & 52 & Reduced number of exacerbations & {$[51]$} \\
\hline MENSA study & Mepolizumab & 576 & 52 & Reduced number of exacerbations & {$[52]$} \\
\hline SIRIUS study & Mepolizumab & 135 & 20 & Reduced oral corticosteroid dose & {$[53]$} \\
\hline OSMO study & Mepolizumab & 145 & 32 & Reduced number of exacerbations & {$[54]$} \\
\hline MUSCA study & Mepolizumab & 551 & 24 & Improvement in the SGRQ total score & {$[55]$} \\
\hline Two phase 3 study (study 1 and study 2) & Reslizumab & 953 & 24 & Reduced number of exacerbations & {$[56]$} \\
\hline SIROCCO study & Benralizumab & 1,205 & 48 & Reduced number of exacerbations & {$[57]$} \\
\hline CALIMA study & Benralizumab & 1,306 & 56 & Reduced number of exacerbations & {$[58]$} \\
\hline ZONDA study & Benralizumab & 220 & 28 & Reduced oral corticosteroid dose & {$[59]$} \\
\hline BORA study & Benralizumab & 1,578 & 56 & Validated 2-year safety of benralizumab use & {$[60]$} \\
\hline
\end{tabular}

$\mathrm{FEV}_{1}$ - forced expiratory volume in the first second; ACQ - asthma control questionnaire; AQLQ - asthma quality of life questionnaire; SGRQ - Sain George's respiratory questionnaire.

asthma, and improved asthma control. Phase 3 studies on benralizumab for severe eosinophilic asthma are presented in Table 1. This medication seems to be theoretically more powerful than mepolizumab and reslizumab in mediating a sustained control of type- 2 inflammation [50].

GM-CSF and IL-3 are implicated in the pathogenesis of a range of diseases. Although the role of GM-CSF and IL-3 in mediating emergency myelopoiesis has been known for a long time, uncovering their role as mediators of innate immune memory has paved the way for new mechanistic investigations on the effects of GM-CSF and IL-3 on the innate immune system. GM-CSF and IL-3 are now considered critical modulators of the innate immune response by acting directly on mature immune cells. These cytokines are still under investigation as therapeutic targets for some diseases, including asthma. Phase 1/2 clinical trials are currently underway. Some of these trials already showing that blocking antibodies against GM-CSF and IL-3-specific receptor $\alpha$ subunits or $\beta c$ subunits can be safe and effective in inflammatory diseases [61]. Phase 2 , randomised placebo-controlled trial to evaluate the efficacy and safety of an anti-GM-CSF antibody in patients with inadequately controlled asthma results show that FEV1 in prespecified groups of participants treated with anti-GM-CSF compared with placebo showed improvements in patients with eosinophilic asthma [62]. There is evidence that IL-3 through alpha subunit-specific properties uniquely influences eosinophil biology and may serve as a potential therapeutic target also [27].

Anti-cytokine therapies have not succeeded in asthma treatment in all patients at the moment. Therefore, newer therapies are being developed that target pathways involved in asthma pathogenesis [22]. Therapies that broadly target integrins would offer the possibility of potently suppressing eosinophil-related pathologies with greater specificity and with lesser side-effects compared with current treatments. Such therapy could target recruitment mechanisms involving 4 and 2 integrins [12]. One of the integrins suppressing agent is RGDS (Arg-Gly-Ser-Asp) peptide as a nonselective integrin receptor antagonist working through $\alpha 4$ integrin or $\alpha \mathrm{M} \beta 2$ integrin [63]. It was shown that integrins suppression by this peptide reduced eosinophils adhesion, decreased the effects of eosinophils on TGF- $\beta 1$, WNT-5a, and extracellular matrix protein gene expression in airway smooth muscle cells together with their proliferation [36]. Moreover, RGDS reduced the in vivo-allergen activated eosinophils effect on airway smooth muscle cells COL1A1 and FN gene expression [64].

Several inhibitors that target impact integrin heterodimers have been devised to prevent the recruitment or quantity of eosinophils in the airways of asthmatic patients and thus, reducing eosinophilic airway. Most therapeutic strategies involving integrins of eosinophils have targeted 4 , the common subunit of 41 , the most important counter-receptor of eosinophils recognizing VCAM-1, and 47, potentially important in recognition of MAdCAM-1 [12]. Blockade of integrin and adhesion receptor interaction could result in decreased eosinophils accumulation in tissues [38]. That is why, as a means to suppress the impact of inflammation on airway remodeling and airway structural cells, has emerged as a potential therapeutic approach for asthma [39]. Integrins are validated drug targets of the US FDA for acute coronary syndromes, psoriasis, and multiple sclerosis, respectively. For example, efalizumab is for the treatment of psoriasis. It was observed that this medication reduce the accumulation of eosinophils in the airway and attenuates the late asthmatic response of human subjects with atopic asthma. However, none has been approved for indications related to respiratory diseases yet [63]. The effectiveness of integrins has 


\section{Moksliniai darbai ir apžvalgos}

been studied in several clinical trials. The first phase 1 clinical trial was published in 2002. This trial and later trials results showed that anti-integrin therapy decreases allergen-induced airway inflammatory and airway hyperresponsiveness, reduces the percentage of eosinophils in sputum, prevents eosinophil extravasations [13]. In general, clinical trials that have been performed demonstrated clinically significant benefits in many patients, leading to continued interest in the further development of novel integrin inhibitors [65].

\section{CONCLUSION}

Eosinophilopoietins are important cytokines responsible for eosinophil maturation and activation and are the primary target for controlling eosinophil functions. So far, only anti-IL-5 or anti-IL-5R therapy has achieved sufficient success, and research with anti-IL-3 and anti-GM-CSF therapy due to lack of specificity for eosinophils is slow. Integrins are another important class of eosinophil surface molecules that are closely related to their functions. Blockade of eosinophil integrins may inhibit their functions, contributing to the reduced airway infiltration and further adverse effects of eosinophils. Antibodies to integrins are not yet widely used, but further research is needed in this area.

Gauta 20200801

Priimta 20200828

\section{REFERENCES}

1. Holgate ST, Wenzel S, Postma DS, Weiss ST, Renz H, Sly PD. Asthma. Nat Rev Dis Primers. 2015; 1:15025.

2. Rogliani P, Calzetta L, Matera MG, Laitano R, Ritondo BL, Hanania NA, et al. Severe asthma and biological therapy: when, which, and for whom. Pulm Ther. 2020; 6(1):47-66.

3. Desai D, Brightling C. Cytokine and anti-cytokine therapy in asthma: ready for the clinic? Clin Exp Immunol. 2009; 158(1):10-9.

4. Ilmarinen P, Kankaanranta H. Eosinophil apoptosis as a therapeutic target in allergic asthma. Basic Clin Pharmacol Toxicol. 2014; 114(1):109-17.

5. Simon HU, Yousefi S, Germic N, Arnold IC, Haczku A, Karaulov AV, et al. The cellular functions of eosinophils: Collegium Internationale Allergologicum (CIA) Update 2020. Int Arch Allergy Immunol. 2020; 181(1):11-23.

6. Guthridge MA, Stomski FC, Thomas D, Woodcock JM, Bagley CJ, Berndt MC, et al. Mechanism of activation of the GM-CSF, IL-3, and IL-5 family of receptors. Stem Cells. 1998; 16(5):301-13.

7. Panousis C, Dhagat U, Edwards KM, Rayzman V, Hardy MP, Braley H, et al. CSL311, a novel, potent, therapeutic monoclonal antibody for the treatment of diseases mediated by the common beta chain of the IL-3, GM-CSF and IL- 5 receptors. MAbs. 2016; 8(3):436-53.

8. Esnault S, Kelly EA. Essential mechanisms of differential activation of eosinophils by IL-3 compared to GM-CSF and IL-5. Crit Rev Immunol. 2016; 36(5):429-44.

9. McBrien CN, Menzies-Gow A. The biology of eosinophils and their role in asthma. Front Med (Lausanne). 2017; 4:93.

10. Lin SC, Shi LS, Ye YL. Advanced molecular knowledge of therapeutic drugs and natural products focusing on inflammatory cytokines in asthma. Cells. 2019; 8(7).

11. Ginsberg MH. Integrin activation. BMB Rep. 2014; 47(12):6559.
12. Barthel SR, Johansson MW, McNamee DM, Mosher DF. Roles of integrin activation in eosinophil function and the eosinophilic inflammation of asthma. J Leukoc Biol. 2008; 83(1):1-12.

13. Teoh CM, Tan SS, Tran T. Integrins as therapeutic targets for respiratory diseases. Curr Mol Med. 2015; 15(8):714-34.

14. Weller PF, Spencer LA. Functions of tissue-resident eosinophils. Nat Rev Immunol. 2017; 17(12):746-60.

15. Davoine F, Lacy P. Eosinophil cytokines, chemokines, and growth factors: emerging roles in immunity. Front Immunol. $2014 ; 5: 570$.

16. O'Sullivan JA, Bochner BS. Eosinophils and eosinophilassociated diseases: An update. J Allergy Clin Immunol. 2018; 141(2):505-17.

17. Park YM, Bochner BS. Eosinophil survival and apoptosis in health and disease. Allergy Asthma Immunol Res. 2010; 2(2):87-101.

18. Ueki S, Tokunaga T, Fujieda S, Honda K, Hirokawa M, Spencer LA, et al. Eosinophil ETosis and DNA traps: a new look at eosinophilic inflammation. Curr Allergy Asthma Rep. 2016; 16(8):54.

19. Bystrom J, Amin K, Bishop-Bailey D. Analysing the eosinophil cationic protein--a clue to the function of the eosinophil granulocyte. Respir Res. 2011; 12:10.

20. Walsh GM. Targeting eosinophils in asthma: current and future state of cytokine- and chemokine-directed monoclonal therapy. Expert Rev Clin Immunol. 2010; 6(5):701-4.

21. Radonjic-Hoesli S, Valent $P$, Klion AD, Wechsler ME, Simon HU. Novel targeted therapies for eosinophil-associated diseases and allergy. Annu Rev Pharmacol Toxicol. 2015; 55:633-56.

22. Dougan M, Dranoff G, Dougan SK. GM-CSF, IL-3, and IL-5 family of cytokines: regulators of inflammation. Immunity. 2019; 50(4):796-811.

23. Broughton SE, Dhagat U, Hercus TR, Nero TL, Grimbaldeston MA, Bonder CS, et al. The GM-CSF/IL-3/IL-5 cytokine receptor family: from ligand recognition to initiation of signaling. Immunol Rev. 2012; 250(1):277-302.

24. Akuthota P, Weller PF. Eosinophils and disease pathogenesis. Semin Hematol. 2012; 49(2):113-9.

25. Esnault S, Kelly EA, Shen ZJ, Johansson MW, Malter JS, Jarjour NN. IL-3 maintains activation of the p90S6K/RPS6 pathway and increases translation in human eosinophils. J Immunol. 2015; 195(6):2529-39.

26. Kandikattu HK, Upparahalli Venkateshaiah S, Mishra A. Synergy of interleukin (IL)-5 and IL-18 in eosinophil mediated pathogenesis of allergic diseases. Cytokine Growth Factor Rev. 2019; 47:83-98.

27. Nelson RK, Brickner H, Panwar B, Ramirez-Suastegui C, Herrera-de la Mata S, Liu N, et al. Human eosinophils express a distinct gene expression program in response to IL-3 compared with common beta-chain cytokines IL-5 and GM-CSF. J Immunol. 2019; 203(2):329-37.

28. Lampinen M, Carlson M, Hakansson LD, Venge P. Cytokineregulated accumulation of eosinophils in inflammatory disease. Allergy. 2004; 59(8):793-805.

29. Martinez-Moczygemba M, Huston DP. Biology of common beta receptor-signaling cytokines: IL-3, IL-5, and GM-CSF. J Allergy Clin Immunol. 2003; 112(4):653-65; quiz 66.

30. Johansson MW. Activation states of blood eosinophils in asthma. Clin Exp Allergy. 2014; 44(4):482-98.

31. Gregory B, Kirchem A, Phipps S, Gevaert P, Pridgeon C, Rankin SM, et al. Differential regulation of human eosinophil IL-3, IL-5, and GM-CSF receptor $\alpha$-chain expression by cytokines: IL-3, IL-5, and GM-CSF down-regulate IL-5 receptor a expression with loss of IL-5 responsiveness, but up-regulate IL-3 receptor a expression. J. Immunol. 2003; 170(11):5359-66.

32. Kalinauskaite-Zukauske V, Januskevicius A, Janulaityte I, Miliauskas S, Malakauskas K. Expression of eosinophil $\beta$ chain-signaling cytokines receptors, outer-membrane integrins, and type 2 inflammation biomarkers in severe non-allergic eosinophilic asthma. BMC Pulm Med. 2019; 19(1):1-12.

33. Fulkerson PC, Rothenberg ME. Targeting eosinophils in allergy, inflammation and beyond. Nat Rev Drug Discov. 2013; 12(2):117-29.

34. Kalinauskaite-Zukauske V, Januskevicius A, Janulaityte I, Miliauskas S, Malakauskas K. Expression of eosinophil beta chain-signaling cytokines receptors, outer-membrane integrins, 


\section{Moksliniai darbai ir apžvalgos}

and type 2 inflammation biomarkers in severe non-allergic eosinophilic asthma. BMC Pulm Med. 2019; 19(1):158.

35. Johansson MW, Mosher DF. Integrin activation States and eosinophil recruitment in asthma. Front Pharmacol. 2013; 4:33.

36. Januskevicius A, Gosens R, Sakalauskas R, Vaitkiene S, Janulaityte I, Halayko AJ, et al. Suppression of eosinophil integrins prevents remodeling of airway smooth muscle in asthma. Front Physiol. 2017; 7:680.

37. Johansson MW. Eosinophil activation status in separate compartments and association with asthma. Front. Med. 2017; $4(75)$.

38. Johansson MW, Mosher DF. Integrin activation states and eosinophil recruitment in asthma. Front Pharmacol. 2013; 4:33.

39. Johansson MW, Annis DS, Mosher DF. $\alpha M \beta 2$ integrin-mediated adhesion and motility of IL-5-stimulated eosinophils on periostin. Am J Respir Cell Mol Biol. 2013; 48(4):503-10.

40. Johansson MW, Annis DS, Mosher DF. Alpha(M)beta(2) integrin-mediated adhesion and motility of IL-5-stimulated eosinophils on periostin. Am J Respir Cell Mol Biol. 2013 48(4):503-10.

41. Carbonell WS, DeLay M, Jahangiri A, Park CC, Aghi MK. $\beta 1$ integrin targeting potentiates antiangiogenic therapy and inhibits the growth of bevacizumab-resistant glioblastoma. Cancer Res. 2013; 73(10):3145-54

42. Barthel SR, Annis DS, Mosher DF, Johansson MW. Differential engagement of modules 1 and 4 of vascular cell adhesion molecule-1 (CD106) by integrins $\alpha 4 \beta 1$ (CD49d/29) and $\alpha \mathrm{M} \beta 2(\mathrm{CD} 11 \mathrm{~b} / 18)$ of eosinophils. J Biol Chem. 2006 281(43):32175-87.

43. Joseph J, Benedict S, Safa W, Joseph M. Serum interleukin-5 levels are elevated in mild and moderate persistent asthma irrespective of regular inhaled glucocorticoid therapy. BMC Pulm Med. 2004; 4(1):1.

44. Busse WW. Biological treatments for severe asthma: A major advance in asthma care. Allergol Int. 2019; 68(2):158-66.

45. Lawrence MG, Steinke JW, Borish L. Cytokine-targeting biologics for allergic diseases. Ann Allergy Asthma Immunol. 2018; 120(4):376-81.

46. Flood-Page P, Swenson C, Faiferman I, Matthews J, Williams M, Brannick L, et al. A study to evaluate safety and efficacy of mepolizumab in patients with moderate persistent asthma. Am J Respir Crit Care Med. 2007; 176(11):1062-71.

47. Edris A, De Feyter S, Maes T, Joos G, Lahousse L. Monoclonal antibodies in type 2 asthma: a systematic review and network meta-analysis. Respir Res. 2019; 20(1):179.

48. Bakakos A, Loukides S, Bakakos P. Severe eosinophilic asthma. J Clin Med. 2019; 8(9).

49. Maspero J. Reslizumab in the treatment of inadequately controlled asthma in adults and adolescents with elevated blood eosinophils: clinical trial evidence and future prospects. Ther Adv Respir Dis. 2017; 11(8):311-25.

50. Pelaia C, Vatrella A, Bruni A, Terracciano R, Pelaia G. Benralizumab in the treatment of severe asthma: design, development and potential place in therapy. Drug Des Devel Ther. 2018; 12:619-28.

51. Pavord ID, Korn S, Howarth P, Bleecker ER, Buhl R, Keene ON, et al. Mepolizumab for severe eosinophilic asthma (DREAM): a multicentre, double-blind, placebo-controlled trial. Lancet. 2012; 380(9842):651-9.

52. Ortega HG, Liu MC, Pavord ID, Brusselle GG, FitzGerald JM, Chetta A, et al. Mepolizumab treatment in patients with severe eosinophilic asthma. N Engl J Med. 2014; 371(13):1198-207.
53. Bel EH, Wenzel SE, Thompson PJ, Prazma CM, Keene ON, Yancey SW, et al. Oral glucocorticoid-sparing effect of mepolizumab in eosinophilic asthma. N Engl J Med. 2014; 371(13):1189-97.

54. Chapman KR, Albers FC, Chipps B, Munoz X, Devouassoux G, Bergna M, et al. The clinical benefit of mepolizumab replacing omalizumab in uncontrolled severe eosinophilic asthma. Allergy. 2019; 74(9):1716-26.

55. Chupp GL, Bradford ES, Albers FC, Bratton DJ, Wang-Jairaj J, Nelsen LM, et al. Efficacy of mepolizumab add-on therapy on health-related quality of life and markers of asthma control in severe eosinophilic asthma (MUSCA): a randomised, doubleblind, placebo-controlled, parallel-group, multicentre, phase 3b trial. Lancet Respir Med. 2017; 5(5):390-400.

56. Castro M, Zangrilli J, Wechsler ME, Bateman ED, Brusselle GG, Bardin P, et al. Reslizumab for inadequately controlled asthma with elevated blood eosinophil counts: results from two multicentre, parallel, double-blind, randomised, placebocontrolled, phase 3 trials. Lancet Respir Med. 2015; 3(5):355-66.

57. Bleecker ER, FitzGerald JM, Chanez P, Papi A, Weinstein SF, Barker P, et al. Efficacy and safety of benralizumab for patients with severe asthma uncontrolled with high-dosage inhaled corticosteroids and long-acting beta2-agonists (SIROCCO): a randomised, multicentre, placebo-controlled phase 3 trial. Lancet. 2016; 388(10056):2115-27.

58. FitzGerald JM, Bleecker ER, Nair P, Korn S, Ohta K, Lom matzsch $\mathbf{M}$, et al. Benralizumab, an anti-interleukin-5 receptor alpha monoclonal antibody, as add-on treatment for patients with severe, uncontrolled, eosinophilic asthma (CALIMA): a randomised, double-blind, placebo-controlled phase 3 trial. Lancet. 2016; 388(10056):2128-41.

59. Nair P, Wenzel S, Rabe KF, Bourdin A, Lugogo NL, Kuna P, et al. Oral glucocorticoid-sparing effect of benralizumab in severe asthma. N Engl J Med. 2017; 376(25):2448-58.

60. Busse WW, Bleecker ER, FitzGerald JM, Ferguson GT, Barker P, Sproule S, et al. Long-term safety and efficacy of benralizumab in patients with severe, uncontrolled asthma: 1 -year results from the BORA phase 3 extension trial. Lancet Respir Med. 2019; 7(1):46-59.

61. Borriello F, Galdiero MR, Varricchi G, Loffredo S, Spadaro G, Marone G. Innate immune modulation by GM-CSF and IL-3 in health and disease. Int J Mol Sci. 2019; 20(4).

62. Molfino NA, Kuna P, Leff JA, Oh CK, Singh D, Chernow M, et al. Phase 2, randomised placebo-controlled trial to evaluate the efficacy and safety of an anti-GM-CSF antibody (KB003) in patients with inadequately controlled asthma. BMJ Open. 2016; 6(1):e007709.

63. Ahmadzai M, Small M, Sehmi R, Gauvreau G, Janssen LJ. Integrins are mechanosensors that modulate human eosinophi activation. Front Immunol. 2015; 6.

64. Janulaityte I, Januskevicius A, Kalinauskaite-Zukauske V, Bajoriuniene I, Malakauskas $\mathrm{K}$. In vivo allergen-activated eosinophils promote collagen I and fibronectin gene expression in airway smooth muscle cells via TGF- $\beta 1$ signaling pathway in asthma. Int J Mol Sci. 2020; 21(5):1837.

65. Ley K, Rivera-Nieves J, Sandborn WJ, Shattil S. Integrinbased therapeutics: biological basis, clinical use and new drugs. Nat Rev Drug Discov. 2016; 15(3):173-83.

66. Kips JC, O'Connor BJ, Langley SJ, Woodcock, A, Kerstjens, H. A, Postma, D. S.et al. Effect of SCH55700, a humanized antihuman interleukin-5 antibody, in severe persistent asthma: a pilot study. Am J Respir Crit Care Med. 2003; 167(12):1655-9. 